\title{
Mapping ecosystem services for planning and management
}

\author{
Benis Egoh $^{\text {a,b,c,* }}$, Belinda Reyers ${ }^{b}$, Mathieu Rouget ${ }^{c, 1}$, David M. Richardson ${ }^{\text {a }}$, \\ David C. Le Maitre ${ }^{\mathrm{b}}$, Albert S. van Jaarsveld ${ }^{\mathrm{a}, 2}$ \\ ${ }^{a}$ Centre for Invasion Biology, Department of Botany E Zoology, Stellenbosch University, Private Bag X1, Matieland 7602, South Africa \\ ${ }^{\mathrm{b}}$ Natural Resources and the Environment, Council for Scientific and Industrial Research, PO Box 320, Stellenbosch 7599, South Africa \\ ${ }^{\mathrm{c}}$ South African National Biodiversity Institute Private Bag X101, Pretoria 0001, South Africa
}

\section{A R T I C L E I N F O}

\section{Article history:}

Received 4 September 2007

Received in revised form 27 March 2008

Accepted 27 March 2008

Available online 19 May 2008

\section{Keywords:}

Conservation biogeography

Conservation planning

Water

Soil

Carbon

Primary productivity

\begin{abstract}
A B S T R A C T
This study mapped the production of five ecosystem services in South Africa: surface water supply, water flow regulation, soil accumulation, soil retention, and carbon storage. The relationship and spatial congruence between services were assessed. The congruence between primary production and these five services was tested to evaluate its value as a surrogate or proxy ecosystem service measure. This study illustrates that (1) most of South Africa's land surface is important for supplying at least one service, (2) there are low levels of congruence between the service ranges and even lower levels between the hotspots for different ecosystem services, and (3) primary production appears to show some potential as a surrogate for ecosystem service distribution. The implications of a heterogeneous landscape for the provision of ecosystem services and their management are highlighted and the potential for managing such services in a country like South Africa is discussed.
\end{abstract}

(c) 2008 Elsevier B.V. All rights reserved.

\section{Introduction}

Several studies have reported a widespread decline in and unsustainable use of ecosystem services across the world (WRI, 2001; MEA, 2005). Areas that are important for maintaining ecosystem components and functions that provide ecosystem services have to be carefully managed to secure the provision of ecosystem services presently and in future (van Jaarsveld et al., 2005; Chan et al., 2006; Egoh et al., 2007). Cowling et al. (in press) proposed an operational framework for mainstreaming the management of ecosystem services into all resource management sectors. This framework highlights the need to combine assessments of the biophysical, economic and social context with considerations of implementation opportunities and constraints into strategy development, implementation and management involving stakeholders. This study addresses the biophysical assessment which is similar in some respects to the assessment phase of systematic conservation planning which deals with the

\footnotetext{
* Corresponding author. Fax: +27 866140506.

E-mail address: benis@sun.ac.za (B. Egoh).

1 Current address: Conservation Science Group, Department of Zoology, University of Cambridge, Downing Street, Cambridge CB2 3EJ, UK.

${ }_{2}^{2}$ Current address: National Research Foundation, PO Box 2600, Pretoria 0002, South Africa.
}

identification of geographic areas to ensure the effective conservation of biodiversity.

The aims of this study were to develop national-scale maps of selected ecosystem services in South Africa to inform and direct agencies responsible for their management, to develop methods for mapping these ecosystem services, and to evaluate the relationships between these services in order to assess whether a particular service can act as an umbrella or surrogate for other services. In addressing these aims, this study borrowed extensively from the field of conservation planning and the lessons learnt from biogeography, which have proved useful in mapping biodiversity pattern and process for use in spatially-explicit decision making (Whittaker et al., 2005).

Conservation planning has come to rely heavily on the notion of surrogates (van Jaarsveld et al., 1998). Surrogacy is a relationship between an "indicator" parameter and an "objective" parameter (sometimes called a "target" parameter, what we ultimately hope to conserve) (Sarkar et al., 2005). For example, conservation biologists often use well studied taxa as surrogates for poorly studied groups. This study relies on these ideas of surrogacy, where ecosystem components and functions are often used as the surrogate or proxy for mapping the distribution of an ecosystem service. The notion of surrogacy between services (and primary productivity) is also tested to examine the potential for umbrella services. 
South Africa is an appropriate place to test these ideas on ecosystem services and surrogacy. The country has been the focus of much conservation planning and biodiversity surrogate research (van Jaarsveld et al., 1998; Cowling et al., 2003), as well as agricultural and hydrological research (Schulze, 1997; Schoeman et al., 2002). Many good biophysical databases and assessment techniques are available (Balmford, 2003). In addition, the Southern African Millennium Ecosystem Assessment included South Africa in its analyses of ecosystem services (Biggs et al., 2004; van Jaarsveld et al., 2005), initiating the collation of new databases on ecosystem services.

\section{Method}

Our study area, South Africa, covers approximately 1.22 million $\mathrm{km}^{2}$. The country is classified as semi-arid and the rainfall varies geographically from less than 50 to about $3000 \mathrm{~mm}$ per year (annual mean $\pm 450 \mathrm{~mm}$ ). The low and uneven distribution of rainfall coupled with very few perennial rivers (most of them shared with other countries) makes South Africa a water scarce country (Biggs et al., 2004). The soils are mostly very shallow with limited irrigation potential (Laker, 2005). They are extremely vulnerable to various forms of degradation (e.g. soil erosion, crusting and loss of organic matter) and have low resilience (Mills and Fey, 2004; Laker, 2005). Agriculture in South Africa is highly industrialized and food production relies largely on irrigation; $\pm 50 \%$ of the total water consumption is for irrigation and demand is increasing (Ministry of Agriculture and Land Affairs, 1998).

South Africa has a large human population of about 47 million (Stats SA, 2005). A large proportion of the population lives in rural areas on private commercial farms ( 1.5 million households) and the communal lands of the former homelands (2.3 million households) (van Horen and Eberhard, 1995). Most of the rural people survive as subsistence farmers and about $90 \%$ of the country's food consumption is met by domestic production with an ever increasing demand (Shackleton et al., 2001). Poverty alleviation is a national priority and initiatives such as payments for ecosystem services are being explored. Payments for ecosystem services are part of the emerging environmental investment sector in South Africa and are based on the commoditization of ecosystem services such as water supply and carbon storage (Peace Parks Foundation, 2005). Some of the country's semi-arid ecosystems store exceptionally large amounts of carbon (Mills et al., 2005).

\subsection{Mapping ecosystem services}

This study selected a suite of nationally relevant ecosystem services from de Groot et al. (2002)'s list of 23 ecosystem services. These include: surface water supply, water flow regulation, carbon storage, soil retention and accumulation. Surface water supply was separated from water flow regulation because of the complexity of the water provision service and the need to capture different components of the functions that are part of this service.

During mapping, ranges and hotspots were distinguished as has been done in spatial biodiversity assessments. We define the range of ecosystem services as areas of meaningful supply, similar to a species' range or area of occupancy. The term "hotspots" was proposed by Norman Myers in the 1980s and refers to areas of high species richness, endemism and/or threat and has been widely used to prioritise areas for biodiversity conservation. Similarly, this study suggests that hotspots for ecosystem services are areas of critical management importance for the service. Here the term ecosystem service hotspot is used to refer to areas which provide large proportions of a particular service, and do not include measures of threat or endemism.
Several data sets were combined to produce a map for a service. Here thresholds were set for both the range and hotspot for each dataset and combined, implying that all areas within the ecosystem service range lie within the ranges of underlying layers. In some cases this integration of datasets had already been done prior to our study and thresholds for the single integrated layer were used.

\subsubsection{Surface water supply}

A number of previous ecosystem service studies have used water production, i.e. the volume of water produced by area, as an ecosystem service or as a surrogate for an ecosystem service (e.g. van Jaarsveld et al., 2005; Chan et al., 2006). Although the amount of water is an important benefit, it is not necessarily an ecosystem service on its own. The amount and distribution of rainfall is the primary determinant of the amount of water produced from a watershed. Rainfall patterns, in turn, depend mainly on abiotic factors such as regional climate systems and topography and not the ecosystems per se. Where the ecosystem does play a key role is in stabilising soils and filtering pollutants (e.g. fertilisers and pesticides), and thus regulating the water quality - the filtering service of de Groot et al. (2002). The total benefit to people of water supply is a function of both the quantity and quality with the ecosystem playing a key role in the latter. However, due to the lack of suitable national scale data on water quality for quantifying the service, runoff was used as an estimate of the benefit where runoff is the total water yield from a watershed including surface and subsurface flow. This assumes that runoff is positively correlated with quality, which is the case in South Africa (Allanson et al., 1990). Most of the country's surface water is generated in a few areas with high runoff: $50 \%$ of the runoff is generated by catchments comprising only $12 \%$ of the total area. Management of these areas will maintain or improve water quality because when they are kept in a good condition they yield high quality water, with the lowest possible soil erosion, nutrient and sediment loss (Scanlon et al., 2007).

In South Africa, water resources are mapped in water management areas called catchments (vs. watersheds) where a catchment is defined as the area of land that is drained by a single river system, including its tributaries (DWAF, 2004). There are 1946 quaternary (4th order) catchments in South Africa, the smallest is 4800 ha and the average size is 65,000 ha. Schulze (1997) modelled annual runoff for each quaternary catchment. During modelling of runoff, he used rainfall data collected over a period of more than 30 years, as well as data on other climatic factors, soil characteristics and grassland as the land cover. In this study, median annual simulated runoff was used as a measure of surface water supply. The volume of runoff per quaternary catchment was calculated for surface water supply. The range (areas with runoff of 30 million $\mathrm{M}^{3}$ or more) and hotspots (areas with runoff of 70 million $\mathrm{M}^{3}$ or more) were defined using a combination of statistics and expert inputs due to a lack of published thresholds in the literature.

\subsubsection{Water flow regulation}

Water flow regulation is a function of the storage and retention components of the water supply service (de Groot et al., 2002). The ability of a catchment to regulate flows is directly related to the volume of water that is retained or stored in the soil and underlying aquifers as moisture or groundwater; and the infiltration rate of water which replenishes the stored water (Kittredge, 1948; Farvolden, 1963). Groundwater contribution to surface runoff is the most direct measure of the water regulation function of a catchment.

Data on the percentage contribution of groundwater to baseflows were obtained from DWAF (2005) per quaternary 
catchment and expressed as a percentage of total surface runoff, the range and hotspot being defined as areas with at least $10 \%$ and $30 \%$, respectively (Colvin et al., 2007).

\subsubsection{Soil retention}

Areas where vegetation cover retains soils need to be managed carefully to allow for the continuous delivery of the services supporting land productivity and preventing damage from erosion through sedimentation and eutrophication of nearby rivers. Soil erosion removes nutrients and reduces fertility (DeFries et al., 2004). In South Africa large productive grazing areas have been lost through soil erosion (Kakembo and Rowntree, 2003).

Soil retention was modelled as a function of vegetation or litter cover and soil erosion potential. Schoeman et al. (2002) modelled soil erosion potential and derived eight erosion classes, ranging from low to severe erosion potential for South Africa. The vegetation cover was mapped by ranking vegetation types using expert knowledge of their ability to curb erosion. We used Schulze (2004) index of litter cover which estimates the soil surface covered by litter based on observations in a range of grasslands, woodlands and natural forests. According to Quinton et al. (1997) and Fowler and Rockstrom (2001) soil erosion is slightly reduced with about $30 \%$, significantly reduced with about $70 \%$ vegetation cover. The range of soil retention was mapped by selecting all areas that had vegetation or litter cover of more than $30 \%$ for both the expert classified vegetation types and litter accumulation index within areas with moderate to severe erosion potential. The hotspot was mapped as areas with severe erosion potential and vegetation/litter cover of at least $70 \%$ where maintaining the cover is essential to prevent erosion. An assumption was made that the potential for this service is relatively low in areas with little natural vegetation or litter cover.

\subsubsection{Soil accumulation}

Soil scientists often use soil depth to model soil production potential (soil formation) (Heimsath et al., 1997; Yuan et al., 2006). The accumulation of soil organic matter is an important process of soil formation which can be badly affected by habitat degradation and transformation (de Groot et al., 2002). Soil depth and leaf litter were used as proxies for soil accumulation. Soil depth is positively correlated with soil organic matter (Yuan et al., 2006); deep soils have the capacity to hold more nutrients. Litter cover was described above. Data on soil depth were obtained from the land capability map of South Africa and thresholds were based on the literature (Schoeman et al., 2002; Tekle, 2004). Areas with at least $0.4 \mathrm{~m}$ depth and $30 \%$ litter cover were mapped as important areas for soil accumulation, i.e. its geographic range. The hotspot was mapped as areas with at least $0.8 \mathrm{~m}$ depth and a $70 \%$ litter cover.

\subsubsection{Carbon storage}

In this study, only carbon storage was mapped because of a lack of data on the other functions related to the regulation of global climate such as carbon sequestration and the effects of changes in albedo. Carbon is stored above or below the ground and South African studies have found higher levels of carbon storage in thicket than in savanna, grassland and renosterveld (Mills et al., 2005). This information was used by experts to classify vegetation types (Mucina and Rutherford, 2006), according to their carbon storage potential, into three categories: low to none (e.g. desert), medium (e.g. grassland), high (e.g. thicket, forest) (Rouget et al., 2004). All vegetation types with medium and high carbon storage potential were identified as the range of carbon storage. Areas of high carbon storage potential where it is essential to retain this store were mapped as the carbon storage hotspot.

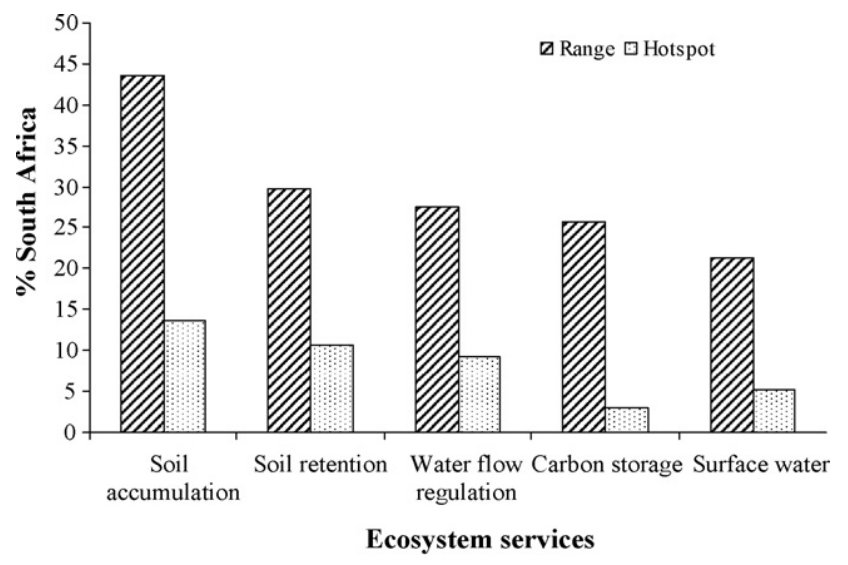

Fig. 1. Percentage of South Africa that is important for the delivery of various ecosystem services, based on the geographical ranges and hotspots of the services. Both natural and transformed areas were included.

\subsection{Evaluating ecosystem service congruence}

The coarsest resolution in the data sets was the scale of catchments (watersheds) and thus all other data (soil accumulation, soil retention and carbon storage) were converted to this resolution. The delivery of each of the services was summarised as the median per catchment and relationships between services were evaluated using Spearman's rank correlations. Primary productivity per catchment from Schulze (1997) was included in the correlation analysis because primary productivity is believed to be a good surrogate for ecosystem function (Tilman et al., 1997). Spatial overlap between services was calculated using proportional overlap (Prendergast et al., 1993) which expresses the area shared between two services as a percentage of the area of the service with a smaller total area. Service richness was expressed as the number of service ranges, as well as hotspots, per catchment. Only catchments where the range or hotspot of a service covered more than an arbitrary yet inclusive threshold of $10 \%$ of the catchment were included in the richness analysis.

\section{Results}

Soil accumulation had the largest range, covering about $43 \%$ of South Africa (Fig. 1). Soil retention also had a relatively large range of about one third of the country, followed by water flow regulation (28\%) and carbon (26\%). Surface water supply showed the smallest range of $21 \%$. The carbon storage hotspot had the smallest area (3\%) of all hotspots and soil accumulation the largest (14\%).

The maps of service richness (Figs. 2 and 3) mirrored the distribution of the two water services and carbon storage. Interestingly, the areas that were most important for surface water supply differed from those important for water flow regulation. Surface water supply was highest in the east, while areas important for water flow regulation were mostly in the central and northern parts of the country. This was partly because the high supply areas were found mainly in eastern montane areas with shallow soils over bedrock and little storage. Carbon storage was greatest in the eastern and northern areas. Unlike the water and carbon services which clustered in the same areas, the soil services were evenly distributed across the country, except in the south west.

Ninety-four percent of catchments in South Africa delivered at least one service, but few catchments produced more than three services. Only $5 \%$ of the catchments produced all five services when 


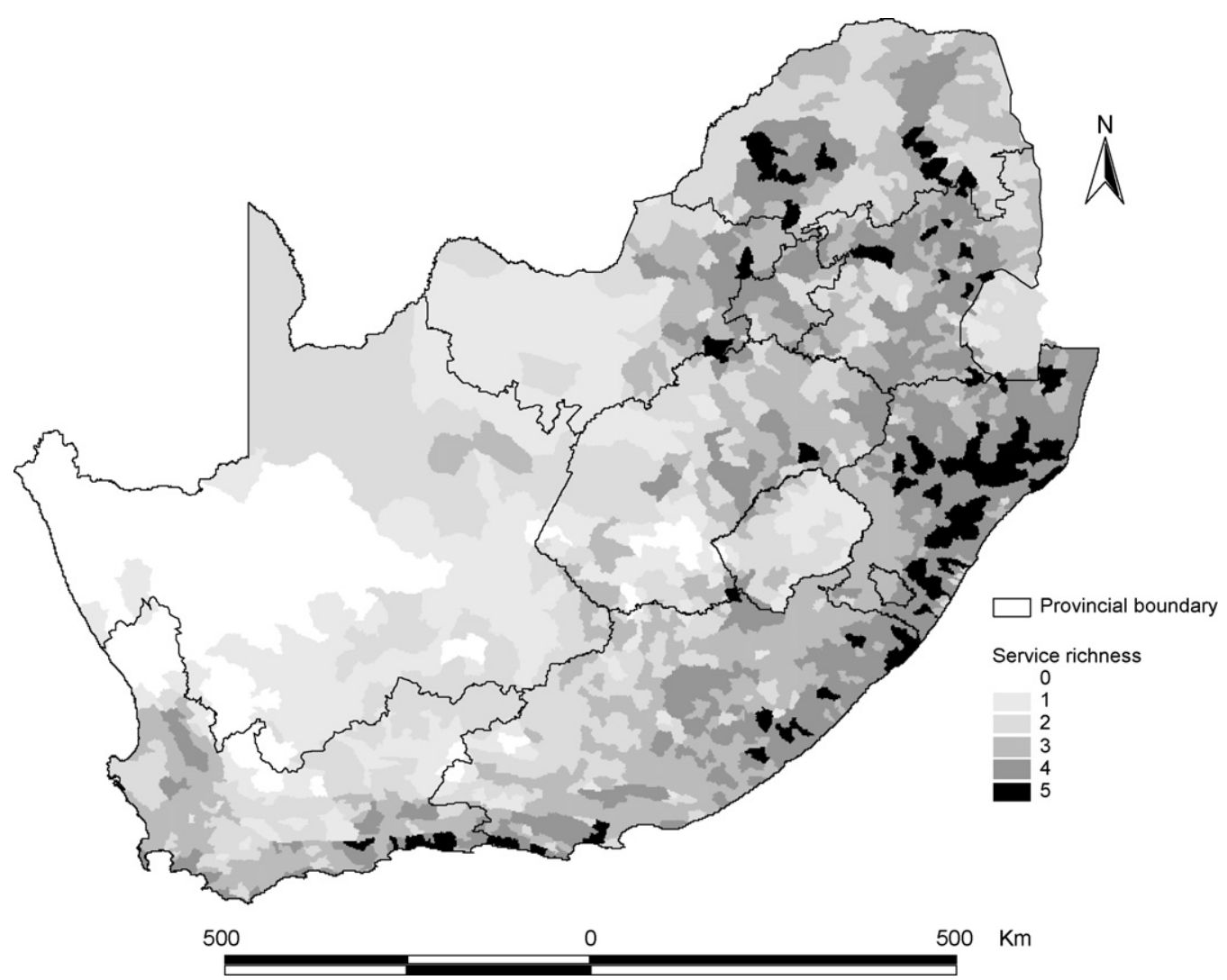

Fig. 2. The number of ecosystem service ranges per catchment. The hotspot of a service is nested within its range.

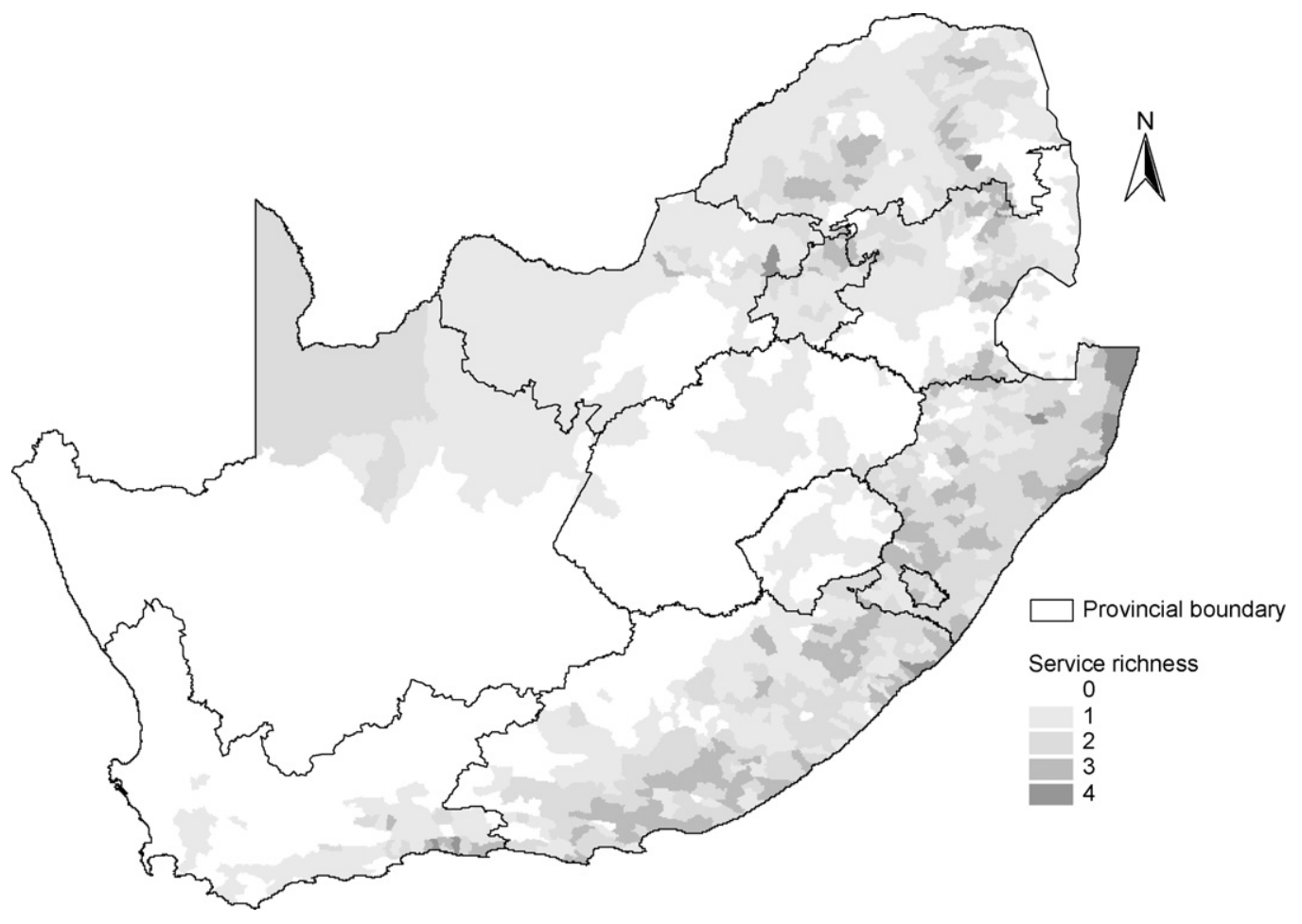

Fig. 3. The number of ecosystem service hotspots per catchment. 
Table 1

Correlation values for ecosystem service (hotspots are shown in brackets)

\begin{tabular}{lcccc}
\hline & Surface water supply & Water flow regulation & Soil accumulation & Soil retention \\
\hline Surface water & - & & & \\
Water flow regulation & $-0.08(-0.09)$ & - & - & $0.56(0.44)$ \\
Soil accumulation & $0.14(-0.15)$ & $0.14(0.14)$ & -0.14 & - \\
Soil retention & 0.23 & $0.14(-0.08)$ & 0.05 & -0.17 \\
Carbon storage & 0.08 & $0.31(0.14)$ & $-0.2)$ & $-0.65(0.24)$ \\
Primary productivity & $0.5(0.25)$ & -0.14 & - \\
\hline
\end{tabular}

Only significant correlations are reported $(p<0.05)$.

Table 2

Proportional overlap of ecosystem services ranges and hotspots (hotspots are shown in brackets)

\begin{tabular}{llcc}
\hline & Water flow regulation & Surface water supply & Soil retention \\
\hline Surface water & $38.7(7.1)$ & - & \\
Soil accumulation & $55.9(12.9)$ & $52.5(20.7)$ & - \\
Soil retention & $33.6(7.7)$ & $37.8(8.8)$ & $47.1(40.3)$ \\
Carbon & $39.7(7.5)$ & $27.2(4.4)$ & $52.3(19.8)$ \\
\hline
\end{tabular}

the ranges were considered and none were a hotspot for all five services (Figs. 2 and 3). Some $30 \%$ of all catchments, mostly in the northern, eastern and southern parts of the country, produced at least four services, but only $7 \%$ were hotspots for four services, all of which were situated in the north and east.

\subsection{Relationships between services}

\subsubsection{Ranges}

Correlations between service ranges were generally low with more positive correlations than negative ones (Table 1). Soil retention showed a relatively strong positive correlation with other services, especially with soil accumulation and surface water supply. Correlation between surface water supply and water flow regulation was negative. Surprisingly, carbon storage showed a very weak and mostly negative correlation with other services and primary productivity. However, correlations between primary production and the other services were moderately strong and mostly positive. The three services that showed a relatively strong positive correlation with each other (surface water supply, soil accumulation and retention), were also positively correlated with primary productivity. Primary productivity was highly correlated $(r=0.5, p<0.05)$ with ecosystem service richness (number of services per catchment). Despite the generally weak correlations between services, spatial overlap of areas providing services was relatively high ( $>30 \%$; Table 2 ). Soil accumulation had the highest spatial overlap of more than $45 \%$ with all other services.

\subsubsection{Hotspots}

The correlations between ecosystem service hotspots were generally weaker than between service ranges (Table 1 ). Again soil retention showed the strongest positive correlation with soil accumulation. Despite the relatively high correlation between the ranges of soil retention and surface water supply, the correlation between the hotspots was not significant. Correlations between primary productivity and hotspots of services were weaker than those for the ranges. The correlation between primary productivity and the number of services per catchment was also high for hotspots $(r=0.5, p<0.05)$. Spatial overlap between services was much lower for hotspots than for ranges (Table 2).

\section{Discussion}

Although the ranges of most of the ecosystem services occupy less than one third of the country (Fig. 1), the low levels of congruence suggest that almost all of the country is important for supplying at least one service with few areas supplying more than three services (Table 2, Fig. 2). The heterogeneity of South Africa's landscape and its ecosystem services has important consequences for their management. Although this study only mapped five ecosystem services, these results imply that management for these and other services will be a resource and land intensive task, with little hope of focusing efforts on small areas which deliver multiple ecosystem services. This aligns with findings on the distribution of biodiversity where $50 \%$ of the country is important for conserving South Africa's diversity of species and ecosystems (Reyers et al., 2007) and carries with it the same dubious distinction and large responsibility that the richness of South Africa's biodiversity carries for conservation biologists (Cowling et al., 1989).

Ecosystem service hotspots in our study are comparable to biodiversity hotspots based on species richness (see Reid, 1998). By focusing on ecosystem service hotspots, managers could potentially reduce the resources and effort required. This has been the case in South Africa where mountain catchments were set aside as protected areas for water production (Rouget et al., 2003). However, these hotspots are open to the same criticisms levelled at biodiversity hotspots, in that they do not necessarily achieve the goals of conservation or management because they are neither systematic nor based on a goal or objective (Margules and Pressey, 2000). The even lower levels of congruence and correlation between hotspots (Tables 1 and 2) parallel the findings of studies on biodiversity hotspots (Williams et al., 1996), and support calls to develop systematic approaches for planning for ecosystem services (Cowling et al., in press), rather than relying on a scoring or hotspots approach.

The weak correlations between ecosystem services assessed in this study and in Chan et al. (2006) demonstrate that one cannot use one ecosystem service to plan for others. This agrees with findings in conservation biology where support for biodiversity surrogates is varied, and most authors recommend using all available data (Lombard et al., 2003 but see Sarkar et al., 2005). Although services do not appear to act as surrogates for other services, our findings of a correlation between most of the services and primary productivity offers some hope for the use of primary productivity as a surrogate for ecosystem function and services, especially in areas where no service data are available at appropriate planning scales. The factors driving primary productivity are important drivers for many services, hence the observed pattern. Carbon storage does not appear to show this relationship. This is possibly due to the scale and expert-opinion based nature of 
our map of carbon storage. However, the extraordinary carbon storage potential found in low production areas in the east of the country (Mills et al., 2005) is an indication that production and accumulation are not necessarily driven by the same factors. Correlation between primary productivity and ecosystem services only applies anyhow to our suite of ecosystem services at a broad scale, and weakly to some of them, suggesting caution in the use of primary productivity as an ecosystem service surrogate.

\section{Acknowledgements}

This work was supported by the International Foundation for Science (Stockholm, Sweden) through a grant to BE, the National Research Foundation (NRF) through the DST-NRF Centre of Excellence for Invasion Biology (CIB) at Stellenbosch University, the South African National Biodiversity Institute(SANBI), Council for Scientific and Industrial Research (CSIR), and Stellenbosch University. Some of the data were provided by School of Bioresources Engineering and Environmental Hydrology, University of KwaZulu Natal, Pietermaritzburg, South Africa. We are grateful to the many experts who contributed to this work, especially Philip Desmet, Richard Cowling, Simon Lorenzo and Anthony Mills.

\section{Reference}

Allanson, B.R., Hart, R.C., O'Keeffe, J.H., Robarts, R.D., 1990. Inland Waters of Southern Africa: An Ecological Perspective. Kluwer Academic Publishers, Dordrecht, The Netherlands.

Balmford, A., 2003. Conservation planning in the real world: South Africa shows the way. Trends Ecol. Evol. 18, 435-438.

Biggs, R., Bohensky, E., Desanker, P.V., Fabricius, C., Lymann, T., Misselhorn Musvoto, C., Mutale, M., Reyers, B., Scholes, R.J., Shikongo, S., van Jaarsveld, A.S., 2004 Nature Supporting People: The South African Millennium Ecosystem Assessment. Council for Scientific and Industrial Research, Pretoria, South Africa.

Chan, K.M.A., Shaw, M.R., Cameron, D.R., Underwood, E.C., Daily, G.C., 2006. Conservation planning for ecosystem services. PLoS Biol. 4 (11), e379.

Colvin, C., Le Maitre, D., Saayman, I., Hughes, S., 2007. An Introduction to Aquifer Dependent Ecosystems in South Africa. WRC report TT301/07. Water Research Commission, Pretoria.

Cowling, R.M., Gibbs Russell, G.E., Hoffman, M.T., Hilton-Taylor, C., 1989. Patterns of plant species diversity in southern Africa. In: Huntley, B.J. (Ed.), Biotic Diversity in Southern Africa. Concepts and Conservation. Oxford University Press, Cape Town, pp. 19-50.

Cowling, R.M., Pressey, R.L., Rouget, M., Lombard, A.T., 2003. A conservation plan fo a global biodiversity hotspot-the Cape Floristic Region, South Africa. Biol. Conserv. 112, 191-216

Cowling R.M. Egoh, B., Knight, T A, O'Farrel, P., Reyers, B., Rouget, M., Roux, D., Welz A., Wilhelm-Rechman, A. in press. An operational model for mainstreaming ecosystem services for implementation. Proc. Nat. Acad. Sci. USA.

de Groot, R., Wilson, M.A., Boumans, R.M., 2002. A typology for the classification, description and valuation of ecosystem functions, goods and services. Ecol. Econ. 41, 393-408.

DeFries, R.S., Foley, J.A., Asner, G.P., 2004. Land-use choices: balancing human needs and ecosystem function. Front. Ecol. Environ. 2, 249-257.

Department of Water Affairs and Forestry, South Africa, 2004. Internal Strategic Perspective: Lower Orange Water Management Area. Dwaf Report No. P WMA 14/000/00/0304.(http://www.dwaf.gov.za/Documents/Other/WMA/14/Lower OrangeISPJul04Intro.pdf).

Department of Water Affairs and Forestry, South Africa., 2005. Groundwate Resource Assessment. Phase II. Methodology. Groundwater-Surface Wate Interactions. Department of Water Affairs and Forestry, Pretoria.(http:// www.dwaf.gov.za/Geohydrology/gra2/3aEFinalReportA.pdf).

Egoh, B., Rouget, M., Reyers, B., Knight, A.T., Cowling, M.R., van Jaarsveld, A.S., Welz, A., 2007. Integrating ecosystem services into conservation assessments: a review. Ecol. Econ. 63, 714-721.

Farvolden, R.N., 1963. Geologic controls on ground-water storage and base flow. J. Hydrol. 1, 219-249.

Fowler, R., Rockstrom, J., 2001. Conservation tillage for sustainable agriculture. An agrarian revolution gathers momentum in Africa. Soil Till. Res. 61, 93-107.

Heimsath, A.M., Dietrich, W.E., Nishiizumi, K., Finkel, R.C., 1997. The soil production function and landscape equilibrium. Nature 388, 358-361.

Kakembo, V., Rowntree K.M., 2003. The relationship between land use and soi erosion in the communal lands near Peddie Town, Eastern Cape, South Africa. Land. Degrad. Dev. 14, 39-49.

Kittredge, J., 1948. Forest Influences. McGraw-Hill Book Company, Inc., New York

aker, M.C. 2005. South Africa's soil resources and sustainable development Available from http://www.environment.gov.za/nssd_2005. (accessed August 2007).
Lombard, A.T., Cowling, R.M., Pressey, R.L., Rebelo, A.G., 2003. Effectiveness of land classes as surrogates for species in conservation planning for the Cape Floristic Region. Biol. Conserv. 112, 45-62.

Margules, C.R., Pressey, R.L., 2000. Systematic conservation planning. Nature 405, 243-253.

Millennium Ecosystem Assessment. 2005. Millennium Ecosystem Assessmen Synthesis Report. Island Press, Washington, D.C. http://www.millenniumas sessment.org/en/Synthesis.aspx (accessed August 2007).

Mills, A.J., Cowling, R.M., Fey, M.V., Kerley, G.I.H., Donaldson, J.S., Lechmere-Oertel, R.G., Sigwela, A.M., Skowno, A.L., Rundel, P., 2005. Effects of goat pastoralism on ecosystem carbon storage in semiarid thicket, Eastern Cape South Africa. Austral. Ecol. 30, 797-804.

Mills, A.J., Fey, M.V., 2004. Effects of vegetation cover on the tendency of soil to crust in South Africa. Soil Use Manage. 20, 1-11.

Ministry of Agriculture and Land Affairs, South Africa., 1998. Enhancing Efficiency in Irrigation. In: Agricultural Policy in South Africa: a Discussion Document National Department of Agriculture, Pretoria.

Mucina, L., Rutherford, M., 2006. The Vegetation of South Africa, Lesotho and Swaziland. Strelitzia 19. South African National Biodiversity Institute, Pretoria.

Peace Parks Foundation, 2005. Carbon sequestration in peace parks in Africa: feasibility study to develop a carbon sequestration framework for African peace parks through the use of Geographic Information System (GIS). Peace Parks, Stellenbosch.

Prendergast, J.R., Quinn, R.M., Lawton, J.H., Eversham, B.C., Gibbons, D.W., 1993 Rare species, the coincidence of diversity hot spots and conservation strategies. Nature 356, 335-337.

Quinton, J.N., Edwards, G.M., Morgan, R.P., 1997. The influence of vegetation species and plant properties on runoff and soil erosion; results from a rainfall simulation study in south east Spain. Soil Use Manage. 13, 143-148.

Reid, W., 1998. Biodiversity hotspots. Trends Ecol. Evol. 13, 275-280.

Reyers, B., Rouget, M., Jonas, Z., Cowling, R.M., Driver, A., Maze, K., Desmet, P., 2007. Developing products for conservation decision-making: lessons from a spatial biodiversity assessment for South Africa. Divers. Distrib. 13, 608-619.

Rouget, M., Richardson, D.M., Cowling, R.M., 2003. The current configuration of protected areas in the Cape Floristic Region, South Africa-reservation bias and representation of biodiversity patterns and processes. Biol. Conserv. 112,129-145.

Rouget, M., Reyers, B., Jonas, Z., Desmet, P., Driver, A., Maze, K., Egoh, B., Cowling, R.M. 2004. South African National Spatial Biodiversity Assessment 2004: Technical Report. Volume 1: Terrestrial Component. South African National Biodiversity.

Sarkar, S., Justus, J., Fuller, T., Kelley, C., Garson, J., Mayfield, M., 2005. Effectiveness of environmental surrogates for the selection of conservation area networks. Conserv. Biol. 19, 815-825.

Scanlon, B.R., Jolly, I., Sophocleous, M., Zhang, L., 2007. Global impacts of conversions from natural to agricultural ecosystems on water resources: quantity versus quality. Water Resour. Res. 43 , doi:10.1029/2006WR005486 W03437.

Schoeman, J.L. Van Der Walt, M., Monnik, K.A. Thackrah, J., Malherbe, J., Le Roux, R.E., 2002. Development and Application of a Land Capability Classification System for South Africa. Agricultural Research Council (ARC) Institute for Soil, Climate and Water, Pretoria, GW/A/2000/57.

Schulze, R.E., 1997. South African Atlas of Agrohydrology and Climatology. WRC Report No. TT 82/96. Water Research Commission, Pretoria, South Africa.

Schulze, R.E., 2004. Determination of baseline land cover variable for applications in assessing land use impacts on hydrological responses in South Africa. In: Schulze, R.E, Pike, A. Development and Evaluation of an Installed Hydrological Modelling System. WRC Report Number: 1155/1/04.

Shackleton, C.M., Shackleton, S.E., Cousins, C., 2001. The role of land-based strategies in rural livelihoods: the contribution of arable production, animal hus bandry and natural resource harvesting in communal areas in South Africa. Dev. South. Afr. 18, 581-604.

Statistics South Africa, 2005. Mid-year Population Estimates. Pretoria, South Africa.

Tekle, S.A., 2004. A Soilscape Survey to Evaluate Land for In-field Rainwate Harvesting in the Free State Province, South Africa. M.Sc. Thesis. University of the Free State, Bloemfontein.

Tilman, D., Knops, J., Wedin, D., Reich, P., Ritchie, M., Siemann, E., 1997. The influence of functional diversity and composition on ecosystem processes. Science 277, 1300-1302.

van Horen, C., Eberhard, A., 1995. Energy, environment and the rural poor in South Africa. Dev. South Afr. 12, 197-211.

van Jaarsveld, A.S., Freitag, S., Chown, S.L, Muller, C, Koch, S., Hull, H., Bellamy, C. Kruger, M., Endrody-Younga, S., Mansell, M.W., Scholtz, C.H., 1998. Biodiversity assessment and conservation strategies. Science 279, 2106-2108.

van Jaarsveld, A.S., Biggs, R., Scholes, R., Bohensky, E., Reyers, B., Lynam, T., Musvoto, C., Fabricius, C., 2005. Measuring conditions and trends in ecosystem services at multiple scales: the Southern African Millennium Ecosystem Assessment (SAfMA) experience. Phil. Trans. R. Soc. B 360, 425-441.

Whittaker, R.J., Araújo, M.B., Jepson, P., Ladle, R., Watson, J.E., Willis, K.J., 2005 Conservation biogeography: assessment and prospect. Divers. Distrib. 11, 3-23.

Williams, P. Gibbons, D. Margules, C. Rebelo, A. Humphries, C., Pressey, R. 1996. comparison of richness hot spots, rarity hot spots, and complementary areas for conserving diversity of British birds. Conserv. Biol. 10, 155-174.

World Resources Institute, 2000-2001. People and Ecosystems: The Fraying Web of Life. World Resources Institute, Washington, DC.

Yuan, J.G., Fang, W., Fan, L., Chen, Y., Wang, D.Q., Yang, Z.Y., 2006. Soil formation an vegetation establishment on the cliff face of abandoned quarries in the early stages of natural colonization. Restor. Ecol. 14, 349-356. 